\title{
The Role Transition Researches of the Government in Public Service Outsourcing
}

\author{
Hui Wu, Feng Pan, Yue Zhang \\ Shandong University of Finance and Economics, Jinan, China \\ Email: panfeng mail@163.com
}

Received 8 September 2015; accepted 24 October 2015; published 27 October 2015

Copyright (C 2015 by authors and Scientific Research Publishing Inc.

This work is licensed under the Creative Commons Attribution International License (CC BY). http://creativecommons.org/licenses/by/4.0/

(c) (i) Open Access

\begin{abstract}
Public service outsourcing is a modern public service supply pattern, which the government takes advantage of the market and society to product and supply public services. Because of the characters of innovation, fashion and practicability, public service outsourcing has shown its multiple values and has been popular with the local government. The government mainly plays the role in rule-maker, public service-buyer and order-supervisor. However, in the process of role transition, our government faces ideological, institutional and ability obstacles, either. Therefore, with the purpose of reducing government outsourcing obstacles and improving the level of government management and service, this paper tries to establish a relatively complete system of public service outsourcing and offers several suggestions including perfecting the institutional construction, establishing diversified safeguard mechanisms and strengthening the construction of the government to build a service-oriented government.
\end{abstract}

\section{Keywords}

The Government, Public Service Outsourcing, Role Transition, Outsourcing System

\section{Introduction}

Since the 1970s, "Giant government" disease has spread to most countries around the world, and it has affected the government's quality and efficiency seriously. "Government failure” also leads to the equalization of public service supply. In the view of this status quo, many emerging theories and campaigns which emphasize on market value and government function transformation boom quickly.

Particularly, one of the most representative campaigns is the new public management movement. The advocates claim to establish a decision-making and decision-performing separated administrative system, which left public service supply to market and social force through the form of marketization and privatization. The public 
service outsourcing, popular with many countries, is an innovative public service supply pattern. And the role of government in public service supply also gets to reposition.

Public service outsourcing is a "Government assumption, directional commission, contract management, cash assessment” public service supply pattern. Its essence is that under the premise of macro grasp of public policy, the government introduces market mechanism and uses the available social resources to improve the ability of public service [1]. According to the definition given by OECD, "Public service outsourcing is a kind of behavior that private sectors and organizations on behalf of the government provide public service to relevant agencies, organizations and the public by signing a contract with the government".

Public service outsourcing emerged in some western developed countries in the 1970s. These countries mainly made parts of public service such as urban greening and garbage cleaning, which should be provided by the government, is outsourced to the private sector, enterprises or other social organizations through introducing market competitive mechanism to reduce financial burden and to improve the quality and efficiency of public service. Afterwards, outsourcing scope gradually expanded to higher levels of public management field, for example energy supply, health care, social security and so on. By the end of the 1990s, along with our country's economic society development and the deepening of government institutions reform, public service outsourcing had been introduced to our country and become an important approach of government public service supply.

\section{The Role of the Government in Public Service Outsourcing}

Public service outsourcing means subdividing the public service supply chains and outsourcing the chains like production and supply to private sectors, enterprises or other social organizations. The government's new roles can be summarized as rule-maker, service-buyer and order-supervisor.

\subsection{The Rule-Maker}

On one hand, corresponding levels of the government should formulate laws and regulations of public service outsourcing, and explicitly stipulate outsourcing scope, procedures, management, supervision and other aspects to provide legal basis for its smooth implementation. On December 1, 2009, China promulgated the first government regulation of regulating service outsourcing - "Interim measures for the Ningbo government service outsourcing”. With the legal support and policy guarantee, the achievements of Ningbo service outsourcing have been leading our country. On the other hand, through analyzing and summarizing basic types, specific standards, overall sizes, spatial distributions and supply effects of the region's public service, the local government can determine specific items, numbers, quality criteria and operation thoughts, and then macro grasp public service outsourcing process. In addition, as a rule-maker, the government also has the responsibility and obligation to act well as a decision-facilitator to ensure the smooth implementation of outsourcing decision.

\subsection{The Service-Buyer}

After outsourcing the public services, the government needn't pay the production and supply costs, but this does not mean that the government can revoke raising funds and expenditure responsibility. Instead, the government needs to pay the service fee according to the quality and quantity of the public service served by social organizations and final appraisal results. Specifically, the government will firstly clear contract contents such as outsourcing scope and program, then sign the contract with contractor units and give them corresponding "deposit" by fiscal means like government budget, tax policy and transfer payment, and finally administer rewards or punishments in accordance with measuring performance when the contract is completely fulfilled. Capital adequacy is a security for social organizations to accomplish the task of public service supply, and it is a key to the success of public service outsourcing that the government acts well as a service-buyer.

\subsection{The Order-Supervisor}

The rise of public service outsourcing pattern led to the development of purchasing service industry, so the government should not only regulate the behavior of outsourcing contracts, but also maintain market order, undertaking the duty of the guardian and regulators. Firstly, government departments need to enhance the construction of outsourcing service process and standard system. Timely supervision and accurate appraisal are essential from production, supply to service performance chains. If the contractor unit isn't required to provide service, 
they shall have the power to rectify with a time limit or terminate the contract. On the other hand, with the purpose of public service outsourcing running in a stable and orderly market environment, government and its departments need to make market evaluation and policy research, strengthen the force of legal administration and judicial safeguard, and guard against market risks.

\section{The Government Obstacles in the Implementation of Public Service Outsourcing}

As an imported good, public service outsourcing is the needs of innovating public management and establishing a service-oriented government in our country. However, the government can't solve every problem, so there are many obstacles restricting the development of public service outsourcing.

\subsection{Ideological Obstacle}

"Government purchase service not only builds a form of contract, but also deeply reflects the government's function localization, power boundaries and the relationship between government and society” [2]. But for now, some local governments for their role transformation and professional positioning are not clear. One misunderstanding is that public service outsourcing is a challenge to the authority of government, which will lose public service supply power and is prone to "the hollow government". Also, these local governments and officials don't realize the importance of market and social organizations and their ability of providing public service. Therefore, they are not willing to delegate some functions and don't want to have a try. The other one is that a part of local governments and officials distorted the nature of public service outsourcing, thinking outsourcing production is outsourcing responsibility and "relieving of burden". They don't care how the service outsourcing goes and don't give funds allowance, let alone supervision and appraisal. Regulatory failure easily leads to corruption and "rent-seeking", which is a fatal factor of outsourcing attempt failure.

\subsection{Institutional Obstacle}

Government's role transition needs a complete set of system support, but at present, our country's status quo is institutional change lag and lacking of institutional guarantee. Firstly, laws and regulations are not sound and haven't provided strong legal support for service outsourcing. So far, "Government procurement law of the People's Republic of China" has been enacted for 11 years, but the corresponding procurement regulations are still not to come. And, the public service hasn't been included in the scope of government procurement. Secondly, public service outsourcing lacks of normative mechanism safeguard. At present, our country has not yet formed tube separated systems and mechanisms in the field of social and public undertakings. Without institutional norm and constraint, our government is difficult to thoroughly transform the role of public service's packagers, self-employers and straight-runners to agents, organizers, payers and supervisors [3].

\subsection{Ability Obstacle}

“The government which has strong management ability, technical skills and internal organization and coordination ability is more likely to make public service outsourcing decisions" [4]. However, all levels of the government in our country are short of practice and experience, even if the government intends to perform outsourcing responsibility, but also faces the dilemma of ability shortage. On one hand, most local governments and officials have not received special outsourcing training, lacking of professional knowledge and skills in contract management, bidding, pricing, regulation and other aspects. On the other hand, because of long-term public service monopoly by the government and its subordinate institutions, only a handful of social organizations have outsourcing qualification now, and overall strength is weak. Consequently, we can't form a sound public service market, and can't achieve the government and market equilibrium, either.

\section{Path Analysis of Speeding up the Government's Role Transition in Public Service Outsourcing: A Relatively Complete System of Public Service Outsourcing}

The Twelfth Five-year Plan clearly pointed out that we should change the way of basic public service supply through introducing competitive mechanism and expanding the purchasing service to achieve supply modes di- 
versity. Obviously, public service outsourcing has become a main institutional arrangement for innovating national public service mechanism. This paper tries to establish a relatively complete system of public service outsourcing, led by the government, which the institutional mechanism is more complete, and the public and social organizations adequately participate in the system to reduce government outsourcing obstacles.

Figure 1 shows a relatively complete public service outsourcing system. Every body's responsibility and role are analyzed as follows:

(1) The government: The government should formulate and improve the laws and regulations about service outsourcing, establish supervisory and appraisal agencies, and set up public service outsourcing platform on behalf of the government to operate specific outsourcing matters. Meanwhile, the department of finance is responsible for outsourcing budget and payment, so that service outsourcing has adequate financial support.

(2) Public service outsourcing platform: Outsourcing platform can be a government service outsourcing association, or a special institution, or a vocational school. It's composed of the personnel with professional outsourcing knowledge and operating skills, charging with the following things: Firstly, the platform, on behalf of the government, will deliver outsourcing information, engage bidding and tender, and sign contracts with contractor units and other things to guarantee that outsourcing process is professional and normative. Secondly, the platform can uniformly train contractors' personnel to promote employment and improve the quality of public service.

(3) Contractor unit: Contractor units sign an outsourcing agreement with government by public service outsourcing platform and provide public services to meet the requirements stipulated in the contract. Meanwhile, the contractor unit is also subject to supervisory agency and the public. Contractor unit providing public service quality will directly determine the efficiency of public service outsourcing.

(4) Supervisory agency: Supervisory agency is set up by the government, and is also responsible for the government. This agency can supervise not only contractor units, but also outsourcing platform, and the results will be fed back to the government department.

(5) Trilateral appraisal agency: Trilateral appraisal agency consists of professional appraisal institution, the government appraisal and the public appraisal (satisfaction degree). The appraisal results will be as an important foundation about whether the public service continues to be outsourced and the contractor units are qualified to continue to bid.

(6) The public: the public are both recipients of public service and a part of producers in contractor units. Therefore, if they discover great issues or potential problems during outsourcing process, they have rights to directly report or complain to government departments. Meanwhile, producers of the public will be trained uniformly by public service outsourcing platform.



Figure 1. Government public service outsourcing system. 
The government plays a decisive role in public service outsourcing, so outsourcing reform should start from the government, enhancing system, mechanism and ability construction and reform.

\subsection{Perfecting the Institutional Construction, Enriching the Outsourcing Decision}

A good legal environment is an important safeguard for the implementation of public service outsourcing. First of all, our government should set up a sound system of laws and regulations. The central government should publish "The government procurement regulation" as soon as possible to clear detailed rules. The treasury ought to introduce "The classification of government procurement of public service" according to different characteristics and purchasing standards of public service. Meanwhile, the central government had better macro grasp the overall situation of public service outsourcing in China, formulating unified outsourcing quality, technology, price and other standards as a reference for local governments, and also allows local governments to make appropriate adjustments according to their local situation and environment changes. Meanwhile, local governments need to firstly abide by the laws and regulations, and then make specific implementation details or relevant supporting measures on the basis of the actual situation in the region.

The next, the department of finance should make budget decisions to make a comprehensive arrangement, fair use funds and plan payment. For example, the department of finance can take "basis salary + push money" term of payment to the contractor. Specifically, when signing a contract, the contractor can only get certain percentage (e.g. $20 \%$ or $30 \%$ ) money as start-up capital, and then the contractor will be paid the remaining payment according to contract performance. But all the payments are only approximately equal to the cost of producing and providing the public service, belonging to "basis salary". After the contract is fully performed, the contractor will obtain "push money" according to appraisal results. If the contractor doesn't meet the requirement, it only makes ends meet and isn't eligible to participate in the next outsourcing project.

\subsection{Establishing Diversified Safeguard Mechanisms, Regulating Outsourcing Process}

The first good choice is to establish diversified supervision mechanisms. As is shown in the diagram 1, supervisory agency can supervise not only contractor units, but also outsourcing platform, and the results will be fed back to the government department. Supervisory personnel should be diversified, including government staff, representatives of contractors and the public, professional researchers (such as audit firms) and experts. Meanwhile, supervision form should be diversified, too. Because various forms of supervision can timely find outsourcing problem appeared in outsourcing process and take appropriate measures to minimize the loss. What's more, the supervision mechanism also includes the supervision of the public. If they discover great issues or potential problems during outsourcing process, they have rights to directly report or complain to government departments.

The second is to establish trilateral appraisal mechanisms_-professional institution appraisal, the government appraisal and the public appraisal. Trilateral appraisal mechanisms choose proper standards to quantify evaluation indicators and especially focus on appraising contractor units' service quality and effectiveness, operation management, the uses of funds and social repercussions, etc. What calls for special attention is that professional institution appraisal, the government appraisal indicators are easier to be quantified and reach an unified standard, but the public appraisal is mainly about satisfaction degree, which the result is more subjective and various. Therefore, when choosing respondents, we should give priority to the people who have enjoyed this service, and pay attention to the difference of gender, age and occupation. Only in this way can we get a more persuasive and realistic survey result.

\subsection{Strengthening the Construction of the Government Itself, Pursuing Outsourcing Reform}

Firstly, the government should improve the level of its own professional knowledge and management skills. All levels of government should organize operational and supervisory staff to receive outsourcing training, which aims to improve their professional quality and executive ability. This requires them not only to be familiar with the characteristics of public service, market development status and technical requirement, to master knowledge about legal regulation, contract procedure and risk management, but also to be capable of explaining the essence and significance of public service outsourcing to the public to remove their concern. At the same time, in order 
to arouse social organizations' participation enthusiasm and initiative, the government had better take actions such as propaganda education, field director and preferential policy to make them set up the consciousness of outsourcing and regard taking outsourcing as a symbol of fulfilling social responsibility.

Secondly, it can adopt flexible and various forms of outsourcing. We can take the form of issuing service credentials. Some basic public services for the individual like endowment, health and medical community, compulsory education, are not suitable to be taken on all things by the government, and unable to be provided to all the public, either. So, the people who need the service can use credentials to purchase it. Of course, we can also attract folk capital investment or give the contractor unit some subsidy on per head basis and other forms to participate in public service outsourcing.

\section{References}

[1] Shi, C.D. and Xu, L.C. (2011) Comparative Research of China and the US Government. Journal of Dalian University, 101.

[2] Jia, X.J. (2013) International Experience of Government Purchase of Public Service. People’s Daily, 2013-10-3(5).

[3] Zhao, Q.J. (2011) The Research of the Government's Role in Public Service Outsourcing. Learning and Discovery, 82.

[4] Kim, H.J. (2005) IT Outsourcing In Public Organizations: How Does the Quality of Outsourcing Relationship Affect IT Outsourcing Effectiveness? Seoul National University, Seoul. 